\title{
hPepT1 mediates bacterial tripeptide fMLP uptake in human monocytes
}

\author{
Laetitia Charrier, Adel Driss, Yutao Yan, Vivienne Nduati, Jan-Michael Klapproth, \\ Shanthi V Sitaraman and Didier Merlin
}

\begin{abstract}
Division of Digestive Diseases, Department of Medicine, Emory University School of Medicine, Atlanta, GA, USA
\end{abstract}

\begin{abstract}
Here, we examined hPepT1 expression in the monocytic cell line, KG-1. Reverse transcription polymerase chain reaction (RT-PCR) analysis revealed that $\mathrm{hPepT1}$ is expressed in KG-1 cells, while cDNA cloning and direct sequencing confirmed the sequence of KG-1 hPepT1 (accession number, AY634368). Immunoblotting of cell lysates from KG-1 cells or macrophages isolated from human peripheral blood revealed a $\sim 100 \mathrm{kDa}$ immunoreactive band mainly present in the membrane fraction. Uptake experiments showed that the transport of $20 \mu \mathrm{M}$ radiolabeled Gly-Sarcosine $\left({ }^{14} \mathrm{C}\right] \mathrm{Gly}$-Sar) in $\mathrm{KG}-1$ cells was $\mathrm{Na}^{+}, \mathrm{Cl}^{-}$dependent and disodium 4,4'diisothiocyanatostilbene-2,2'-disulfonate (DIDS)-sensitive. In addition, hPepT1 activity was likely to be coupled to a Na+$/ \mathrm{H}^{+}$exchanger, as evidenced by the fact that $\left[{ }^{14} \mathrm{C}\right] \mathrm{Gly}$-Sar uptake was not affected by the absence of $\mathrm{Na}^{+}$when cells were incubated at low pH (5.2). Interestingly, hPepT1-mediated transport was reduced in KG-1 cells incubated at low pH as it was also observed in nonpolarized Caco2-BBE cells. This pattern of $\mathrm{pH}$-dependence is due to a disruption of the driving force of $\mathrm{hPepT1}$-mediated transport events. This was supported by our finding that nonpolarized cells, Caco2-BBE cells and KG-1 cells, have an increased permeability to $\mathrm{H}^{+}$when compared to polarized Caco2-BBE cells. Finally, we showed that hPepT1 is responsible for transporting fMLP into undifferentiated and differentiated (macrophage-like) KG-1 cells. Together, these results show that hPepT1 is expressed in nonpolarized immune cells, such as macrophages, where the transporter functions best at the physiological pH 7.2. Furthermore, we provide evidence for hPepT1mediated fMLP transport, which might constitute a novel immune cell activation pathway during intestinal inflammation.
\end{abstract}

Laboratory Investigation (2006) 86, 490-503. doi:10.1038/labinvest.3700413; published online 27 March 2006

Keywords: bacterial peptides; cell polarity; fMLP; hPepT1; KG-1; macrophages

It is well known that bacteria such as Escherichia coli (E. coli) release potent chemotactic substances. ${ }^{1}$ Partial characterizations of culture filtrates from $E$. coli have established that some of this chemoattractant bioactivity is related to small heterogeneous peptides with blocked amino groups, called $n$ formyl peptides. ${ }^{1}$ The tripeptide formyl-methionylleucyl-phenylalanine (fMLP), a major peptide chemotactic factor produced by E. coli, ${ }^{2}$ is a major $n$-formylated peptide of the human colonic lumen, ${ }^{1}$ which contains an fMLP equivalent concentration of $\sim 10^{-7} \mathrm{M}^{1}$ It is likely that $n$-formyl peptide concentrations are substantially lower in the small intestine, which has a lower density of procaryotes. In

Correspondence: Dr D Merlin, PhD, Emory University, Division of Digestive Diseases, Department of Medicine, 615 Michael Street, Atlanta, GA 30322, USA.

E-mail: dmerlin@emory.edu

Received 4 January 2006; revised 15 February 2006; accepted 16 February 2006; published online 27 March 2006 some pathological conditions, increased numbers of bacteria present in the lumen of the human intestine lead to elevation of fMLP concentration.

We recently demonstrated that the oligopeptide co-transporter, $\mathrm{hPepT} 1,{ }^{3}$ is expressed in the apical plasma membrane of intestinal epithelia, where it transports bacterial-derived chemotactic peptides such as fMLP. ${ }^{4}$ This was the first demonstration that a major bacterial chemotactic peptide can be transported across the apical plasma membrane of intestinal cells by hPepT1, and was confirmed by a subsequent report that another bacterial product, muramyl dipeptide (MDP), is transported by hPepT1 in intestinal epithelia. ${ }^{5}$ Interestingly, hPepT1 expression is normally restricted to the small intestine, where bacteria are far fewer in number, and was not detected in the normal esophagus, stomach or colon. ${ }^{6-8}$ However, we found that hPepT1 is expressed in colon tissues affected with inflammatory bowel disease $^{9}$ and it has been shown that hPepT1 is upregulated in the colon of 
patients with short-bowel syndrome, ${ }^{10}$ suggesting that hPepT1 may be involved in intestinal pathological states. ${ }^{9}$

As fMLP transport across basolateral membranes is rate limiting, ${ }^{4}$ it seems logical that hPepT1 expression in the presence of a significant luminal concentration of $n$-formyl peptides would lead to the accumulation of these bacterial peptides in the cytoplasm. ${ }^{4}$ Indeed, we recently demonstrated that hPepT1-mediated fMLP uptake can induce intestinal inflammation in vitro and in vivo. ${ }^{11}$ The absorbed fMLP ultimately moves across the basolateral membrane and/or diffuses passively across the tight junctions to the lamina propria, where it may activate immune cells through specific receptors. ${ }^{12}$ Regulation of the transcellular and paracellular movement of fMLP across the epithelium will modulate fMLP concentration in the lamina propria.

The activation of an immune response requires recognition of microorganisms by host receptors such as fMLP receptors or toll-like receptors (TLRs) expressed in immune cells. ${ }^{12-14}$ Recently, alternative receptors called nucleotide-binding site and leucine-rich repeat (NBS-LRR) proteins have been associated with intracellular recognition of microbes and their products (for a review, see Chamaillard et $a 1^{15}$ ). NBS-LRR molecules appear to be a new family of intracellular receptors of innate immunity; they are able to detect specific bacterial compounds such as $\mathrm{MDP}^{15}$ and induce inflammatory responses. The dysregulation of these processes due to mutations in the genes encoding these proteins is involved in numerous autoinflammatory disorders, including Crohn's disease, Blau syndrome, Muckle-Wells syndrome, familial cold autoinflammatory syndrome, and chronic neurologic cutaneous and articular syndrome (for a review, see Chamaillard et $a l^{15}$ ). However, it is not yet known how di- and tripeptides such as MDP and fMLP are taken up by macrophages.

Here, we examine whether di- and tripeptide bacterial products are transported by hPept 1 in immune cells such as macrophages.

\section{Materials and methods}

\section{Cell Culture}

The human monocytic KG-1 cell line was purchased from the ATCC (Rockville, MD, USA) and grown in Iscove's modified Dulbecco's medium (Sigma, St Louis, MO, USA) supplemented with $10 \%(\mathrm{v} / \mathrm{v})$ heat-inactivated fetal bovine serum (FBS, Invitrogen, Grand Island, NY, USA), $4 \mathrm{mM}$ Glutamine (Invitrogen) and 1. $5 \mu \mathrm{g} / \mathrm{ml}$ plasmocin (Invivogen, San Diego, CA, USA). For some experiments, KG-1 cells were seeded at a concentration of 1 million cells $/ \mathrm{ml}$ in $5 \mathrm{ml}$ medium/well in 12-well plates and treated for 4 days with $100 \mathrm{nM}$ PMA (Sigma, St Louis, MO, USA).

The human enterocyte-like Caco2-BBE cell line ${ }^{16-19}$ were grown in high glucose Dulbecco's
Vogt-modified Eagle's media (DMEM, Invitrogen) supplemented with $14 \mathrm{mmol} / \mathrm{l} \mathrm{NaHCO}_{3}, 10 \%$ (v/v) heat-inactivated FBS and $1.5 \mu \mathrm{g} / \mathrm{ml}$ plasmocin. Cells were kept at $37^{\circ} \mathrm{C}$ in $5 \% \mathrm{CO}_{2}$ and $90 \%$ humidity, and the medium was changed every other day. Uptake experiments in nonpolarized intestinal epithelial cells were performed on confluent Caco2-BBE cells cultured on 12-well plates (Costar, VWR, Suwanee, GA, USA). Uptake experiments in polarized intestinal epithelial cells utilized confluent Caco2-BBE monolayers plated on filters (area $1 \mathrm{~cm}^{2}$; pore size $0.4 \mu \mathrm{m}$; Transwell-Clear polyester membranes, Costar, VWR, Suwanee, GA, USA). Cells were used at different culture times after reaching confluency as indicated. Intracellular $\mathrm{pH}$ measurements in nonpolarized intestinal epithelial cells were performed on confluent Caco2-BBE cells cultured on Glass Bottom Microwell Dish (35 mm Petri dish, $14 \mathrm{~mm}$ microwell; MatTek, Ashland, MA, USA). Intracellular $\mathrm{pH}$ measurements in polarized intestinal epithelial cells were performed on confluent Caco2-BBE cells plated on filters (area $1 \mathrm{~cm}^{2}$; pore size $0.4 \mu \mathrm{m}$; Snapwell-Clear polyester membranes, Costar, VWR, Suwanee, GA, USA).

\section{Generation of Polyclonal Antibodies to Human hPepT1}

Based on a computerized predictive model for antigenicity and uniqueness, we designed a synthetic peptide $\left(\mathrm{H}_{2} \mathrm{~N}\right.$-FRHRSKAYPKREHWC-COOH) corresponding to residues 248-261 of the deduced hPepT1 protein. The peptide was coupled to keyhole limpet hemocyanin, and used to raise an antihPepT1 antibody in rabbits via a standard 80-day immunization protocol. The reactivity of the resulting antisera against the peptide was tested by enzyme-linked immunosorbent assay (ELISA), and the antibody was affinity purified against the synthetic peptide. Antibody yields were as follows: rabbit 1: $2 \mathrm{mg} \times 15 \mathrm{ml}$; rabbit $2: 2 \mathrm{mg} / \mathrm{ml} \times 11 \mathrm{ml}$.

\section{Cloning the Full-Length cDNA for KG-1 hPEPT1}

PolyA ${ }^{+}$-RNA was isolated from KG-1 cells and reverse transcribed as previously described. ${ }^{19} \mathrm{~A}$ dilution of the reverse transcription (RT) reaction was used as a template for polymerase chain reaction (PCR) amplification of the full-length hPEPT1 cDNA using specific oligonucleotide primers (sense, $5^{\prime}$-CGCCATGGGAATGTCCAAATC- ${ }^{\prime}$ and antisense, $3^{\prime}$-CCCCGGTTAAGTGTCTTTGTCTAC-5'). After an initial denaturation step at $94^{\circ} \mathrm{C}$ for $5 \mathrm{~min}$, PCR was carried out for 35 cycles (denaturation at $94^{\circ} \mathrm{C}$ for $1 \mathrm{~min}$, annealing at $55^{\circ} \mathrm{C}$ for $2 \mathrm{~min}$ and extension at $72^{\circ} \mathrm{C}$ for $4 \mathrm{~min}$ ), followed by a final cycle (denaturation at $94^{\circ} \mathrm{C}$ for $1 \mathrm{~min}$, annealing at $55^{\circ} \mathrm{C}$ for $2 \mathrm{~min}$ and extension at $72^{\circ} \mathrm{C}$ for $10 \mathrm{~min}$ ). The resulting PCR product $(2117 \mathrm{pb})$ was electrophoresed on an ethidium bromide-stained 1\% agarose gel in TAE. After 
gel extraction using the QIAquick Gel Extraction Kit (Qiagen, Valencia, CA, USA), the PCR product was cloned into pcDNA3.1/V5-His-TOPO (Invitrogen). Plasmids were grown and purified using the Qiagen Maxiplasmid kit (Qiagen), and the insert was sequenced (Lark Technologies, Houston, TX, USA).

\section{Isolation of Normal Human Peripheral Blood Mononuclear Cells}

For isolation of human peripheral blood mononuclear cells (HPBMCs), whole blood was diluted 1:1 with PBS and centrifuged $\left(400 \mathrm{~g}, 25 \mathrm{~min}, 21^{\circ} \mathrm{C}\right.$ ) over Histopaque 1077 (Sigma). The resulting mononuclear cells were seeded in RPMI medium (Invitrogen) supplemented with $10 \%(\mathrm{v} / \mathrm{v})$ heat-inactivated FBS (Invitrogen) and incubated at $37^{\circ} \mathrm{C}$, in $5 \% \mathrm{CO}_{2}$, and $90 \%$ humidity for $4 \mathrm{~h}$ to allow macrophages to adhere to the flask. Nonadherent cells were removed, and the adherent macrophages were washed twice in $1 \times$ PBS, lysed and processed for Western blotting.

\section{Western Blot Analysis}

Cells were lysed for $30 \mathrm{~min}$ at $4^{\circ} \mathrm{C}$ in RIPA buffer (150 mM NaCl, 0.5\%. sodium deoxycholate, $50 \mathrm{mM}$ Tris-HCl, pH 8.0, 0.1\% SDS, $0.1 \%$ NP40) supplemented with protease inhibitors (Roche Diagnostics $\mathrm{GmbH}$, Mannheim, Germany). The homogenates were centrifuged at $13000 \mathrm{~g}$ for $30 \mathrm{~min}$ at $4^{\circ} \mathrm{C}$ and the supernatants (total cellular proteins) were collected for Western blot analysis. Protein concentrations were determined using the Folin assay (DC protein assay kit, Bio-Rad, Hercules, CA, USA). Equal loading amounts of the protein extracts were mixed in Tricine sample buffer (Bio-Rad), run on an $8 \%$ polyacrylamide gel (VWR, Suwanee, GA, USA) without prior denaturation at $90^{\circ} \mathrm{C}$, and then transferred to nitrocellulose membranes. Membranes were blocked overnight at $4^{\circ} \mathrm{C}$ or for $1 \mathrm{~h}$ at room temperature with $5 \%$ nonfat milk in blocking buffer and then incubated for $1 \mathrm{~h}$ at room temperature with a rabbit polyclonal antibody raised against human PepT1 (1:1000) obtained as described above. After washing, membranes were further incubated for $1 \mathrm{~h}$ at room temperature with an antirabbit horseradish peroxidase-conjugated secondary antibody (1:1000; Amersham, Piscataway, NJ, USA). Membranes were washed, and immunoreactive proteins were detected using enhanced chemiluminescence (ECL) according to the manufacturer's instructions (Amersham).

\section{Membrane Preparations}

For membrane preparations, cells were washed twice in PBS and scraped in PBS. The samples were centrifuged ( $400 \mathrm{~g}$ for $5 \mathrm{~min}$ ), and the cell pellets were resuspended and carefully homogenized with a douncer in HEPES buffer $(5 \mathrm{mM})$ containing protease inhibitors. The homogenate was incubated for $30 \mathrm{~min}$ at $4{ }^{\circ} \mathrm{C}$, and then centrifuged at $13000 \mathrm{~g}$ at $4^{\circ} \mathrm{C}$ for $30 \mathrm{~min}$. The resulting pellet was suspended in PBS by repeated passage through an 18-gauge needle. Protein concentrations in the membrane suspension and cytoplasmic fraction were quantified using the Bio-Rad protein assay (Bio-Rad).

\section{Immunofluorescence Staining}

Cells were washed twice with PBS pH 7.4. (Invitrogen) supplemented with $0.1 \mathrm{mM} \mathrm{CaCl}_{2}$ and $1 \mathrm{mM}$ $\mathrm{MgCl}_{2}$ (PBS-Ca/Mg), and fixed in $4 \%$ paraformaldehyde (Electron Microscopy Sciences, Washington, $\mathrm{PA}$, USA) in $\mathrm{PBS}-\mathrm{Ca} / \mathrm{Mg}$ for $15 \mathrm{~min}$ at room temperature. Cells were then washed three times in PBS-Ca/Mg and stored at $4^{\circ} \mathrm{C}$ until future use or directly processed for immunostaining after six washes in immunostaining buffer (PBS-Ca/Mg/BSA $3 \% /$ saponine $0.05 \%$ ). Cells were incubated for $1 \mathrm{~h}$ 30 min at room temperature with a rabbit polyclonal anti-PepT1 antibody diluted (1:200) in immunostaining buffer and washed six times with immunostaining buffer. Cells were then exposed to a goat anti-rabbit antibody conjugated to Alexa Fluor 568 (1:200, Molecular Probes, Eugene, OR, USA) for $1 \mathrm{~h}$ at room temperature. After six washes in immunostaining buffer and one wash in PBS-Ca/Mg, coverslips were mounted by using the Slowfade kit (Molecular Probes). Negative controls were performed by omission of the primary antibody. Microscopy was performed by using a Zeiss epifluorescence microscope equipped with a BioRad MRC600 confocal unit, computer, and laser scanning microscope image analysis software (Carl Zeiss, Jena, Germany). Original magnification $\times 63$.

\section{Uptake Experiments}

For nondifferentiated KG-1 cells, growing in suspension, $5 \times 10^{6}$ cells were used per assay.

Cells were washed twice with $1 \times$ PBS (Invitrogen) stabilized for $15 \mathrm{~min}$ in HBSS (Sigma) supplemented with $10 \mathrm{mM}$ MES (pH6.2, or as indicated) at $37^{\circ} \mathrm{C}$. The samples were then incubated in HBSS$10 \mathrm{mM}$ MES (pH6.2, or as indicated) containing $20 \mu \mathrm{M}\left[{ }^{14} \mathrm{C}\right] \mathrm{Gly}-S a r$ (specific activity: $50 \mathrm{mCi} / \mathrm{mM}$, American Radiolabeled Chemicals, Inc., St Louis, $\mathrm{MO}$, USA) for $1 \mathrm{~h}$ at room temperature, in the presence or absence of $20 \mathrm{mM}$ Gly-Leu (Sigma) used as a competitor for hPEPT1-mediated transport. The same experiments were performed using $0.15 \mu \mathrm{M}$ $\left[{ }^{3} \mathrm{H}\right] \mathrm{fMLP}$ (specific activity: $51.50 \mathrm{Ci} / \mathrm{mM}$, Perkin Elmer, Boston, MA, USA). Afterwards, cells were washed twice in ice-cold $1 \times$ PBS and resuspended in scintillation liquid, and total radioactivity was determined with a $\beta$ counter (1219 Rackbeta, Wallac, Gaithersburg, MD, USA). For some experiments, 
sodium chloride was replaced by choline chloride salt (Sigma) (HBSS without sodium) or by DGluconic acid sodium salt (Sigma) (HBSS without chloride), or the uptake was performed in the presence of $100 \mu \mathrm{M}$ disodium4, $4^{\prime}$-diisothiocyanatostilbene-2,2'-disulfonate (DIDS, Sigma), an inhibitor of cell anion permeability.

For Caco2-BBE cells grown on 12-well plates, cells were used at different culture times, after they reached confluency, and the uptake experiments were performed as described above except that cells were incubated for $15 \mathrm{~min}$ at room temperature in HBSS-10 mM MES (pH 6.2, or as indicated) containing $20 \mu \mathrm{M}\left[{ }^{14} \mathrm{C}\right] \mathrm{Gly}-\mathrm{Sar}$, with or without $20 \mathrm{mM}$ GlyLeu. For experiments using polarized Caco2-BBE cells grown on filters, cells were also used at different culture times, after they reached confluency, and washed twice with HBSS complemented with $10 \mathrm{mM}$ MES ( $\mathrm{pH}$ 7.2) in the basolateral compartment, and with $10 \mathrm{mM}$ MES ( $\mathrm{pH} 5.2, \mathrm{pH}$ 6.2 or $\mathrm{pH} 7.2$ ) in the apical compartment, and stabilized $15 \mathrm{~min}$ in the same buffers at $37^{\circ} \mathrm{C}$. Then, Caco2-BBE monolayers were incubated in HBSS$10 \mathrm{mM}$ MES (pH 6.2), containing $20 \mu \mathrm{M}\left[{ }^{14} \mathrm{C}\right] \mathrm{Gly}-$ Sar $\pm 20 \mathrm{mM}$ Gly-Leu in the apical compartment, and in HBSS-10 mM MES (pH7.2) without $\left[{ }^{14} \mathrm{C}\right] \mathrm{Gly}$-Sar or Gly-Leu in the basolateral compartment for $15 \mathrm{~min}$ at room temperature. The supernatant was then removed, cells were washed twice, filters were cut, and radioactivity was read as described above.

In some experiments, results are expressed as specific uptake of $\left[{ }^{14} \mathrm{C}\right] \mathrm{Gly}-\mathrm{Sar}$ or $\left[{ }^{3} \mathrm{H}\right]$ fMLP. Specific uptakes were calculated as follow: (Uptake of $\left[{ }^{14} \mathrm{C}\right]$ Gly-Sar or $\left.\left[{ }^{3} \mathrm{H}\right] \mathrm{fMLP}\right)-\left(\right.$ Uptake of $\left[{ }^{14} \mathrm{C}\right] \mathrm{Gly}-$ Sar or $\left[{ }^{3} \mathrm{H}\right] \mathrm{fMLP}$ in the presence of Gly-Leu), which represent uptakes specifically mediated by hPepT1.

\section{RT-PCR}

Total RNAs were isolated with a RNeasy Mini Kit (Qiagen Inc., Valencia, CA, USA) following the manufacturer's instructions. Oligonucleotide primers specific for hPepT2, NHE1, NHE2, NHE3 and $\beta$-actin were synthesized. For hPepT2, forward (5'-GAGAAGACTGCTATGCATTGG-3') and reverse ( $5^{\prime}$-ACCTGTGACAGAGAACATGACCTC-3') primers were used to amplify a $1.25 \mathrm{~kb}$ fragment. For NHE1, forward ( $5^{\prime}$-TCTGCCGTCTCCACCGTCTCCA-3 ${ }^{\prime}$ ) and reverse (5'-CCCTTCAGCTCCTCATTCACCA-3') primers were used to amplify a $422 \mathrm{bp}$ fragment from human NHE1. For NHE2, forward (5'-GAAGATGTT TGTGGACATTGGGG-3 ${ }^{\prime}$ ) and reverse (5'-CGTCTGA GTCGCTGCTATTGC- $3^{\prime}$ ) primers were used to amplify a $550 \mathrm{bp}$ fragment from human NHE2. For NHE3, forward (5'-GTTCTTCACCGTCATCTTCCA-3') and reverse (5'-AGCGCTGACATTTTCTCTCAG- $3^{\prime}$ ) primers were used to amplify a $445 \mathrm{bp}$ fragment from human NHE31. For $\beta$-actin, forward $\left(5^{\prime}-\right.$ GTCACCCACACTGTGCCCATC-3') and reverse pri- mers (5'-ACGGAGTACTTGCGCTCAGGA-3') were used to amplify a $542 \mathrm{bp}$ fragment from human $\beta$-actin. RT-PCR experiments were performed using the Super Script One-Step RT-PCR with platinum Taq DNA Polymerase (Invitrogen), according to the manufacturer's instructions. Briefly, RT was carried out at $55^{\circ} \mathrm{C}$ for $30 \mathrm{~min}$. After an initial denaturation step at $94^{\circ} \mathrm{C}$ for $2 \mathrm{~min}$, PCR was carried out for 39 cycles (denaturation at $94^{\circ} \mathrm{C}$ for $15 \mathrm{~s}$, annealing at $55^{\circ} \mathrm{C}$ for $30 \mathrm{~s}$ and extension at $68^{\circ} \mathrm{C}$ for $1 \mathrm{~min} 30 \mathrm{~s}$ ), followed by a final extension at $68^{\circ} \mathrm{C}$ for $5 \mathrm{~min}$ ). The resulting PCR products were electrophoresed on an ethidium bromide-stained $1 \%$ agarose gel in TAE.

\section{Intracellular pH Measurements}

Intracellular pH in Caco2-BBE and KG-1 cells was assessed by ratiometric measurement of fluorescence of the $\mathrm{pH}$-sensitive dye $2^{\prime}, 7^{\prime}$-bis-(2-carboxyethyl)-5 (and-6) carboxyfluorescein, acetoxymethyl ester (BCECF-AM; Molecular Probes, Eugene, OR, USA).

Caco2-BBE cells were loaded with $10 \mu \mathrm{M}$ BCECFAM (Molecular Probes), in culture medium, for $1 \mathrm{~h}$ at $37^{\circ} \mathrm{C}$. Cells were then washed twice in HBSS$10 \mathrm{mM}$ MES pH 7.2 to remove the excess of nonde-esterfied dye. Ratiometric measurements of fluorescence in single Caco2-BBE cells were performed using a workstation (Intracellular Imaging, Cincinnati, OH, USA) consisting of a Nikon TSE 100 Ellipse inverted microscope with epifluorescence attachments. BCECF was successively excited at 440 and $490 \mathrm{~nm}$ by light beams from a $300 \mathrm{~W}$ Xenon lamp. Light emitted from the cells at $535 \mathrm{~nm}$ was detected by a cooled charge-coupled device imaging camera. Cells were monitored via $\times 20$ fluorescence objective (Plan Fluor 20, Nikon). An electronic shutter (Sutter Instruments, Rochester, NY, USA) was used to minimize photobleaching of dye. Protocols were executed and data were collected online with InCyt Im2 software (Intracellular Imaging). Two experiments, that is, two independent cell cultures for both Caco2-BBE cells grown on plastic and Caco2-BBE cells grown on filters were performed. For each experiment, three caco2-BBE cell monolayers were assessed in which 30 cells/ monolayer were selected for intracellular $\mathrm{pH}$ measurement. The data shown represent the mean of intracellular $\mathrm{pH}$ found for one monolayer and are representative of the data obtained for the other monolayers.

KG-1 cells $\left(2.5 \times 10^{6} \mathrm{cells} / \mathrm{ml}\right)$ were loaded with $5 \mu \mathrm{M}$ of BCECF-AM (Molecular Probes), in culture medium, for $30 \mathrm{~min}$ at $37^{\circ} \mathrm{C}$ and washed. Ratiometric measurements of fluorescence in suspensions of KG-1 cells were performed using Hitachi F-4500 fluorescence spectrophotometer (Hitachi, Danbury, CT, USA; excitation wavelengths, $500 / 450 \mathrm{~nm}$; emission wavelength, $530 \mathrm{~nm}$ ). Two independent 
experiments using KG-1 cells were performed. For each experiment, three assays were performed in which 200000 cells were assessed for intracellular $\mathrm{pH}$. The data shown represent the mean of intracellular $\mathrm{pH}$ for 200000 cells (one assay), which are representative of the results found in the six assays.

To convert raw $490 / 440$ or $500 / 450$ ratios to $\mathrm{pH}_{\mathrm{i}}$ values, we applied the nigericin-high-KCl in situ calibration method. ${ }^{20}$ Briefly, we used a series of solutions with $\mathrm{pH}$ values from 6.0-8.0, and we equilibrated $\mathrm{pH}_{\mathrm{i}}$ and extracellular $\mathrm{pH}$ using $10 \mu \mathrm{M}$ of the $\mathrm{K}^{+} / \mathrm{H}^{+}$ionophore nigericin, in the presence of $140 \mathrm{mM} \mathrm{KCl}$ and $10 \mathrm{mM} \mathrm{NaCl}$. The calibration curve was generated by plotting the acquired raw ratios against the known $\mathrm{pH}$ values. The equation of the derived calibration curve was used for the transformation of measured ratio values to $\mathrm{pH}_{\mathrm{i}}$.

All measurements were background corrected and were performed at room temperature.

\section{Statistical Data}

Results are expressed as mean \pm s.e. Statistical significance was determined using the $t$-test for unpaired samples.

\section{Results}

\section{hPepT1 is Expressed in Normal Human Macrophages and Human Monocytic KG-1 Cells}

We first examined whether human normal macrophages from peripheral blood express hPepT1. Human macrophages were isolated from peripheral blood, as described in the 'Materials and methods' section, and were processed for immunoblot experiments. Immunoblotting of human peripheral blood macrophages whole-cell lysates with a rabbit polyclonal anti-hPepT1 antibody revealed an immunoreactive band of about $100 \mathrm{kDa}$ corresponding to hPepT1 (Figure 1a). To further investigate the localization of hPepT1 in human peripheral blood macrophages, immunofluorescence staining was performed. Figure $1 \mathrm{~b}$ shows that hPepT1 is mainly expressed at the membrane. To study hPepT1 activity in human monocytes/macrophages, we used the human monocytic cell line, KG-1. Expression of hPepT1 in these cells was assessed by RT-PCR with primers yielding a $2117 \mathrm{bp}$ fragment corresponding to the cDNA encoding hPepT1 (Figure 1c). The PCR product was purified, subcloned and sequenced, and the resulting DNA sequence (GenBank accession \# AY634368) showed $100 \%$ homology to the a

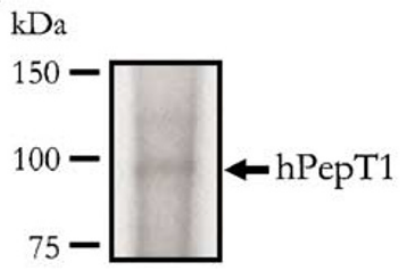

b

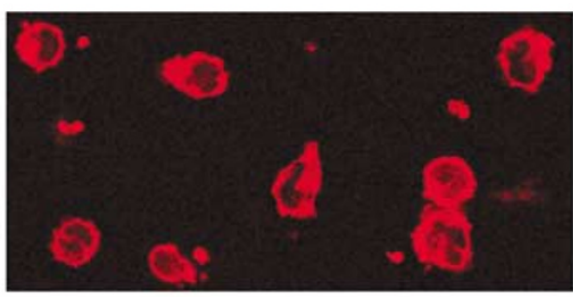

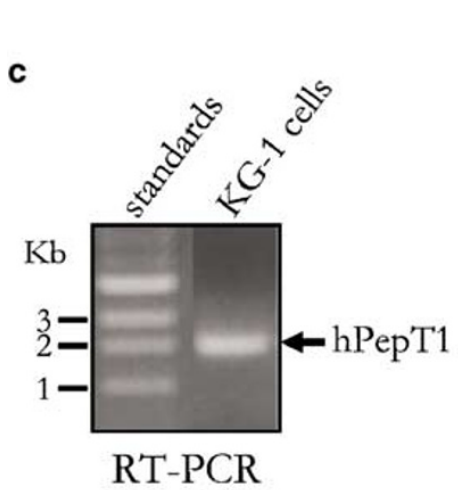

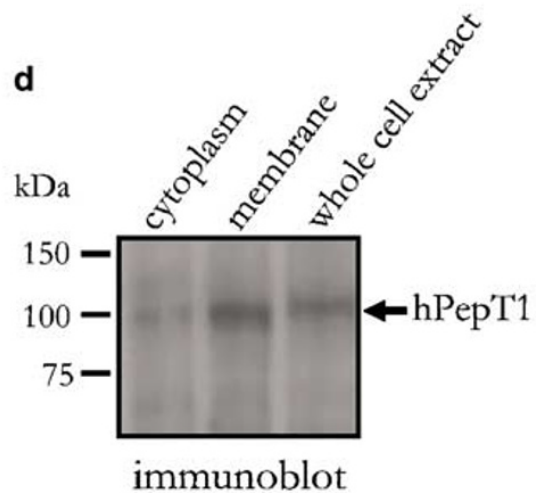

e

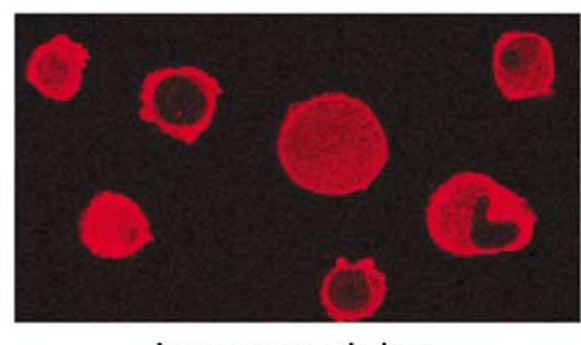

immunostaining

Figure 1 hPepT1 is expressed in KG-1 cells. (a) Immunoblot analysis of hPepT1 expression was performed in whole-cell extracts (50 $\mu$ g protein loaded) of human macrophages, using a polyclonal rabbit anti-hPepT1 antibody. The molecular sizes of the standards are shown on the left (in kDa). (b) Immunofluorescence staining of hPepT1 on human macrophages isolated from peripheral blood. Pictures were taken using a confocal microscope. Original magnification $\times 63$. (c) KG-1 cells were subjected to RT-PCR with full-length hPepT1specific primers, yielding a single band of 2117 bp. (d) Immunoblot analysis of hPepT1 expression in KG-1 cells was performed on wholecell extracts ( $50 \mu \mathrm{g}$ protein loaded), the cytoplasmic fraction ( $30 \mu \mathrm{g}$ protein loaded) and the membrane fraction ( $25 \mu \mathrm{g}$ protein loaded), using a polyclonal rabbit anti-hPepT1 antibody. The molecular sizes of the standards are shown on the left (in kDa). (e) Immunofluorescence staining of hPepT1 on KG-1 cells. Pictures were taken using a confocal microscope. Original magnification $\times 63$. 
published coding sequence of hPepT1 present in Caco2 cells (GenBank accession \# AF043233). Immunoblot experiments were performed on whole-cell extracts and membrane/cytoplasm preparations from KG-1 cells for examination of hPepT1 protein expression in this cell line. Our results revealed a band of about $100 \mathrm{kDa}$ corresponding to hPepT1, which was mainly present in the membrane fraction (Figure 1d). Immunofluorescence staining of hPepT1 on KG-1 cells confirmed the results obtained by immunoblot (Figure 1e). hPepT1 appeared to be mainly expressed at the membrane of KG-1 cells although a slight staining could be observed in the cytoplasm (Figure 1e).

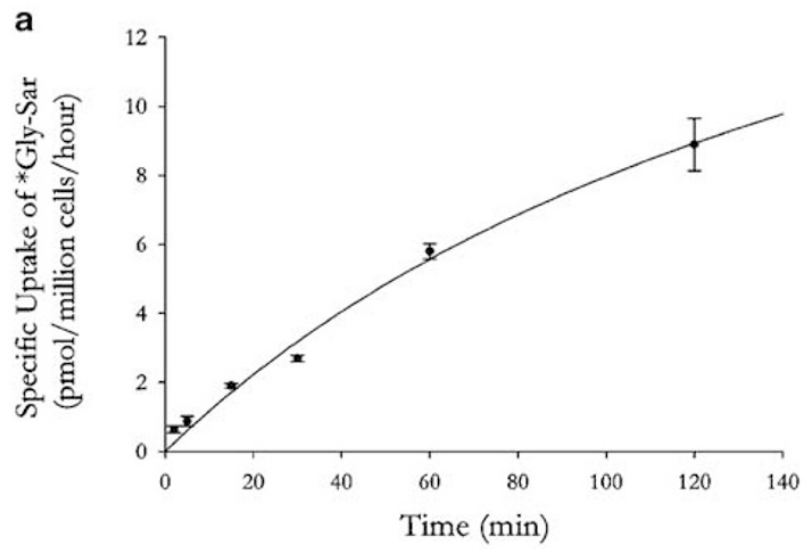

b
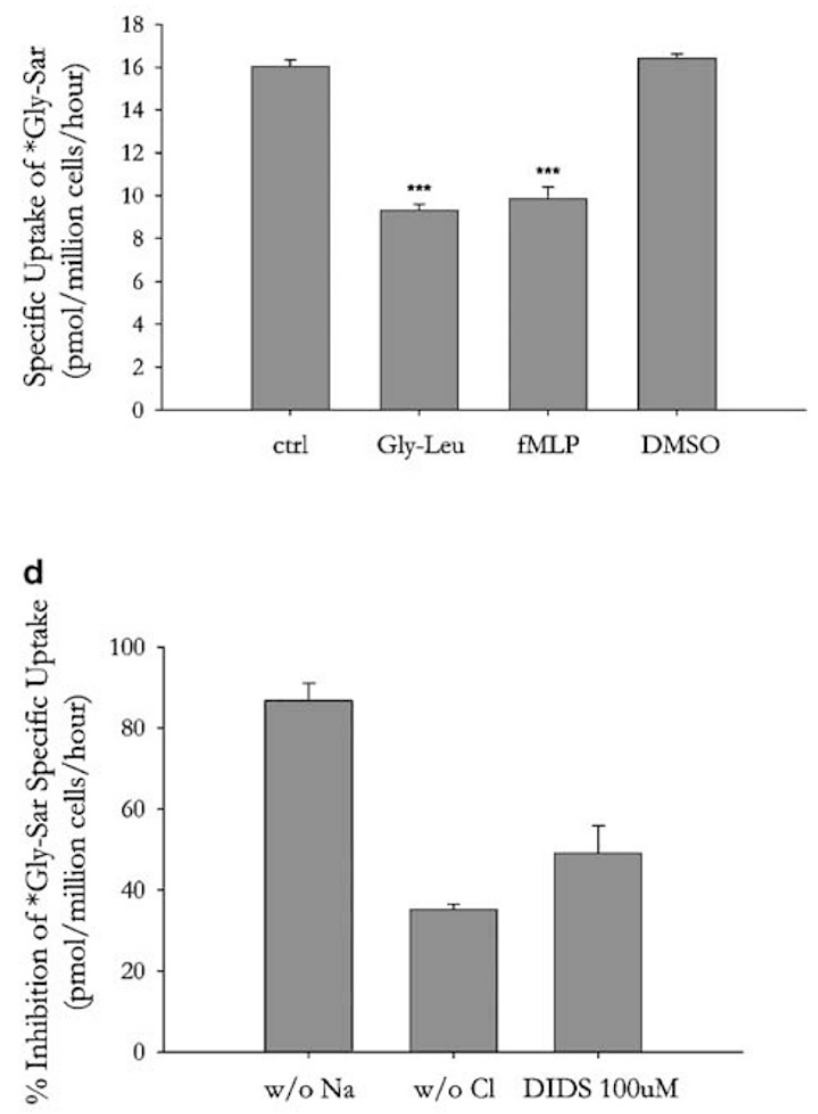

Figure 2 Uptake of di- and tripeptides including fMLP is hPepT1-mediated in KG-1 cells. (a) Time course experiments for the uptake by $\mathrm{KG}-1$ cells of $20 \mu \mathrm{M}\left[{ }^{14} \mathrm{C}\right] \mathrm{Gly}$-Sar with or without $20 \mathrm{mM}$ Gly-Leu were performed to choose a time from the linear range for further uptake experiments. Duration of $1 \mathrm{~h}$ is the time we chose for uptake experiments performed on KG-1 cells. (b) KG-1 cells were incubated at pH 6.2 with $20 \mu \mathrm{M}\left[{ }^{14} \mathrm{C}\right] \mathrm{Gly}$-Sar with or without $20 \mathrm{mM}$ Gly-Leu or $1 \mathrm{mM}$ fMLP or DMSO, used as the vehicle control of fMLP, and radioactivity was determined by liquid scintillation counting. Values are expressed in $\mathrm{pmol} / \mathrm{million}$ cells/h and represent means $\pm \mathrm{s}$.e. of three determinations. ${ }^{* *} P<0.001$ vs control (ctrl). (c) KG-1 cells were incubated at room temperature for $1 \mathrm{~h}$ with varying concentrations of $\left[{ }^{14} \mathrm{C}\right] \mathrm{fMLP}$ (specific activity $16 \mathrm{mCi} / \mathrm{mM}$ ) added to extracellular medium, and the amount of fMLP accumulated by KG-1 cells was determined by liquid scintillation counting. Results are expressed as specific uptake of $\left[{ }^{14} \mathrm{C}\right] \mathrm{Gly}-\mathrm{Sar}$ calculated as described in the 'Materials and methods' section. Values represent means \pm s.e. of three determinations. (d) KG-1 cells were incubated at pH 6.2 with $20 \mu \mathrm{mol} / \mathrm{l}\left[{ }^{14} \mathrm{C}\right] \mathrm{Gly}-\mathrm{Sar}$ in the presence or absence of $\mathrm{Na}^{+}, \mathrm{Cl}^{-}$or DIDS as described in the 'Materials and methods' section, and radioactivity was determined by liquid scintillation. Results are expressed in \% inhibition of $\left[{ }^{14} \mathrm{C}\right] \mathrm{Gly}$-Sar-specific uptake compared with $\left[{ }^{14} \mathrm{C}\right]$ Gly-Sar-specific uptake obtained with regular HBSS buffer containing $\mathrm{Na}^{+}$and $\mathrm{Cl}^{-}$. Specific uptakes were calculated as described in the 'Materials and methods' section. Values represent the means \pm s.e. of three to six determinations; w/o $\mathrm{Na}^{+}$, in absence of $\mathrm{Na}^{+}$; w/o $\mathrm{Cl}^{-}$, in the absence of $\mathrm{Cl}^{-}$; DIDS, in the presence of DIDS. 
about $40 \%$ in the presence of $20 \mathrm{mM}$ unlabeled Gly-Leu $\quad(9.32 \pm 0.28$ vs $16.02 \pm 0.32 \mathrm{pmol} / \mathrm{million}$ cells $/ \mathrm{h}$ ) and by about $38 \%$ in the presence of $1 \mathrm{mM}$ unlabeled fMLP $(9.86 \pm 0.55$ vs $16.02 \pm 0.32$ $\mathrm{pmol} / \mathrm{million}$ cells/h), indicating that Gly-Sarcosine uptake was partially mediated by hPepT1 (Figure 2b). DMSO, the vehicle control for fMLP, did not have any effect on Gly-Sarcosine uptake by KG-1 cells (Figure 2b). However, these results might suggest that other transporter(s) in addition to hPepT1 might be involved in the uptake of GlySarcosine.

To confirm hPepT1-mediated transport of fMLP into KG-1 cells, we performed uptake measurements at varying concentrations of $\left[{ }^{3} \mathrm{H}\right] \mathrm{fMLP}(0.1-$ $100 \mathrm{mM}$ ). Figure 2c shows that fMLP transport across the apical plasma membrane of KG-1 cells was saturable. Kinetic parameters calculated from the Michaelis-Menten equation revealed that the apparent $K_{\mathrm{m}}$ and $V_{\max }$ values for uptake across membrane of KG-1 cells were $2.9 \mathrm{mM}$ and $1.77 \mathrm{nmol} / \mathrm{million}$ cells $/ \mathrm{h}$, respectively. Similar $K_{\mathrm{m}}$ and $V_{\max }$ were found by using the model dipeptide $\left[{ }^{14} \mathrm{C}\right]$ Gly-Sarcosine (results not shown). To further characterize hPepT1-mediated di- and tripeptide uptake in KG-1 cells, we investigated the role of extracellular $\mathrm{Na}^{+}$and $\mathrm{Cl}^{-}$on hPepT1 transport activity. When $\mathrm{Na}^{+}$was replaced by choline in the uptake solution, Gly-Sarcosine uptake was reduced by about $87 \%(86.75 \% \pm 4.35)$, demonstrating that the Gly-Sarcosine uptake was $\mathrm{Na}^{+}$dependent (Figure 2d). In addition, Gly-Sarcosine uptake was reduced by about $50 \% \quad(49.08 \% \pm 6.69)$ in the presence of $100 \mu \mathrm{M}$ disodium 4,4'-diisothiocyanatostilbene-2,2'-disulfonate (DIDS), an inhibitor of cell anion permeability, and by $35 \%(35.13 \% \pm 1.39)$ when $\mathrm{Cl}^{-}$was replaced with D-gluconic acid in the uptake solution, suggesting that an anion-exchange mechanism is involved in Gly-Sarcosine uptake by KG-1 cells (Figure 2d).

\section{hPepT1 Transport Activity is Coupled to $\mathrm{Na} / \mathrm{H}$ Exchange in Monocytic KG-1 Cells}

It is well known that hPepT1-mediated solute transport is coupled with the downhill movement of $\mathrm{H}^{+}$across the apical brush border membrane into the cytoplasm of intestinal epithelial cells., ${ }^{4,16,21 .}$

As KG-1 cells are nonpolarized cells, we investigated the pH-dependence of hPepT1-mediated transport in these cells. Uptake experiments of $20 \mu \mathrm{M}$ radiolabeled $\left[{ }^{14} \mathrm{C}\right] \mathrm{Gly}-$ Sarcosine, in the presence or absence of $20 \mathrm{mM}$ unlabeled Gly-Leu, by KG-1 cells were performed at different pHs. Interestingly, Figure 3a shows that hPepT1 activity increased as extracellular $\mathrm{pH}$ increased $(1.63 \pm$ $0.51 \mathrm{pmol} \quad\left[{ }^{14} \mathrm{C}\right]$ Gly-Sarcosine/million cells/h for pH5.2 vs $4.37 \pm 0.12$ for $\mathrm{pH} 6.2$ vs $5.62 \pm 0.51$ for $\mathrm{pH}$ 7.2). However, when $\mathrm{Na}^{+}$was removed from the uptake medium, hPepT1 activity in KG-1 cells

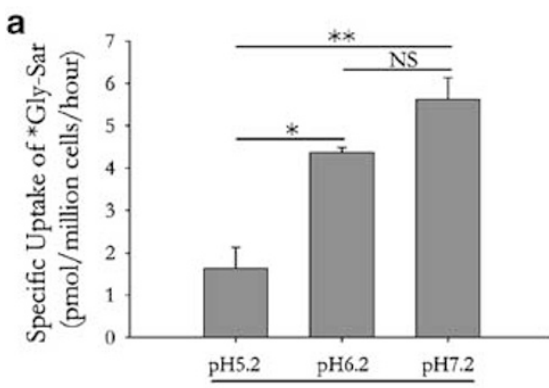

KG-1 cells, in the presence of $\mathrm{Na}^{+}$

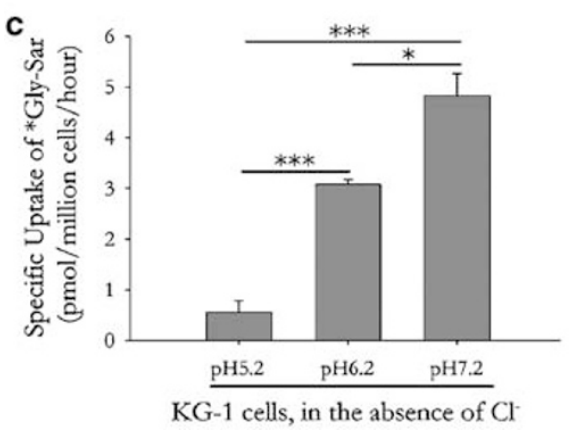

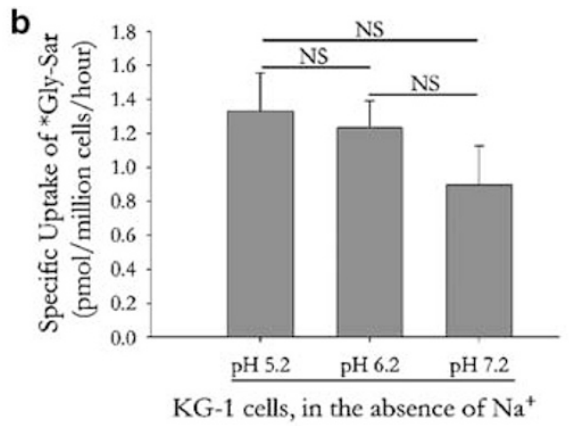
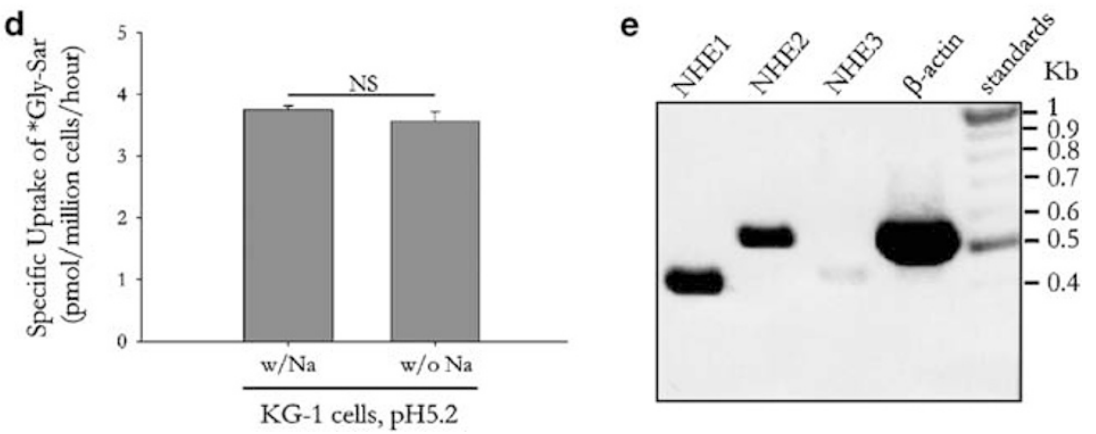

Figure 3 hPepT1 transport activity is coupled to the Na/H exchanger in monocytic KG-1 cells. The pH-dependence of $\left[{ }^{14} \mathrm{C}\right] \mathrm{Gly}-\mathrm{Sar}$ uptake in KG-1 cells was measured after incubation with $20 \mu \mathrm{M}\left[{ }^{14} \mathrm{C}\right] \mathrm{Gly}-\mathrm{Sar} \pm 20 \mathrm{mM}$ Gly-Leu , at pH 5.2, 6.2 or 7.2 , in the presence of $\mathrm{Na}^{+}(\mathbf{a})$, in the absence of $\mathrm{Na}^{+}(\mathbf{b})$, in the absence of $\mathrm{Cl}^{-}$(c) or at pH 5.2, in the presence (w/Na) or absence of Na+ (w/o Na) (d). Results are expressed as specific uptake of $\left[{ }^{14} \mathrm{C}\right] \mathrm{Gly}-\mathrm{Sar}$ calculated as described in the 'Materials and methods' section. Values represent means \pm s.e. of three determinations. ${ }^{*}{ }^{*} P<0.001 ;{ }^{*} P<0.005 ;{ }^{*} P<0.05$; NS, nonsignificant. (e) KG-1 cells were subjected to RT-PCR with specific primers for NHE1, NHE2 and NHE3, yielding bands of 422, 550 and $445 \mathrm{bp}$, respectively. 
tended to decrease as extracellular $\mathrm{pH}$ increased (Figure 3b; $1.33 \pm 0.22 \mathrm{pmol} \quad\left[{ }^{14} \mathrm{C}\right]$ Gly-Sarcosine/ million cells/h for $\mathrm{pH} 5.2$ vs $1.23 \pm 0.16$ for $\mathrm{pH} 6.2$ vs $0.89 \pm 0.23$ for $\mathrm{pH} 7.2$ ), suggesting that hPepT1 activity is dependent on extracellular $\mathrm{Na}^{+}$. In contrast, when $\mathrm{Cl}^{-}$was removed from the uptake medium, higher extracellular $\mathrm{pH}$ still increased hPepT1 activity in KG-1 cells (Figure 3c; 0.56 \pm $0.23 \mathrm{pmol}\left[{ }^{14} \mathrm{C}\right]$ Gly-Sarcosine /million cells/h for pH5.2 vs $3.08 \pm 0.09$ for $\mathrm{pH} 6.2$ vs $4.83 \pm 0.44$ for $\mathrm{pH7.2}$. This suggests that the $\mathrm{Cl}^{-}$-dependence of hPepT1 activity does not involve extracellular $\mathrm{H}^{+}$. Finally, we found that hPepT1 activity in KG-1 cells was not affected by removal of extracellular $\mathrm{Na}^{+}$ when $\mathrm{pH}$ was maintained at 5.2 (Figure 3d; $3.56 \pm 0.15 \mathrm{pmol}\left[{ }^{14} \mathrm{C}\right] \mathrm{Gly}-\mathrm{Sarcosine} / \mathrm{million}$ cells $/ \mathrm{h}$ in the absence of $\mathrm{Na}^{+}$vs $3.75 \pm 0.06$ in the presence of $\mathrm{Na}^{+}$), suggesting an uncoupling between hPepT1 activity and $\mathrm{Na} / \mathrm{H}$ exchange in the presence of a high concentration of $\mathrm{H}^{+}$in the extracellular medium. RT-PCR experiments were performed in order to assess for NHE1, NHE2 and NHE3 mRNA expression in KG-1 cells. Figure 3e shows that three isoforms of the $\mathrm{Na} / \mathrm{H}$ exchanger are expressed in KG-1 cells. However NHE1 and NHE2 appeared to be the main isoforms present in KG-1 cells in comparison with NHE3 whose mRNA expression appeared to be very low (Figure 3e). These results suggest that at least one of these three exchangers is involved in the coupling to hPepT1-mediated activity (Figure 3e).

\section{The pH Dependence of hPepT1-Mediated Uptake is Influenced by Cell Polarity}

We then investigated whether the difference of $\mathrm{pH}$ dependence between KG-1 cells and polarized Caco2-BBE cells is due to the lack of cell polarity

Figure 4 Cell polarity affects the pH-dependence of hPepT1 transport in Caco2-BBE cells. (a) Time course experiments for the uptake by nonpolarized Caco2-BBE cells of $20 \mu \mathrm{M}\left[{ }^{14} \mathrm{C}\right] \mathrm{Gly}-\mathrm{Sar}$ with or without $20 \mathrm{mM}$ Gly-Leu were performed to choose a time from the linear range for further uptake experiments. A $15 \mathrm{~min}$ duration is the time we chose for uptake experiments performed on Caco2-BBE cells. (b) hPepT1-mediated uptake of $\left[{ }^{14} \mathrm{C}\right] \mathrm{Gly}-\mathrm{Sar}$ uptake is increased by basic $\mathrm{pHs}$ in nonpolarized confluent Caco2-BBE cells. Uptake experiments of $20 \mu \mathrm{M} \quad\left[{ }^{14} \mathrm{C}\right] \mathrm{Gly}-$ Sar $\pm 20 \mathrm{mM}$ Gly-Leu by Caco2-BBE monolayers grown on 12well plates after different culture times were performed at different extracellular pHs (pH5.2, 6.2 or 7.2). Cells were then lysed and the remaining intracellular $\left[{ }^{14} \mathrm{C}\right] \mathrm{Gly}$-Sar was measured. (c) hPepT1-mediated uptake of $\left[{ }^{14} \mathrm{C}\right] \mathrm{Gly}$-Sar is optimal at $\mathrm{pH} 6.2$ in polarized Caco2-BBE cell monolayers. Uptake experiments of $20 \mu \mathrm{M} \quad\left[{ }^{14} \mathrm{C}\right]$ Gly-Sar $\pm 20 \mathrm{mM}$ Gly-Leu by confluent Caco2-BBE cells after different culture times were performed at different apical $\mathrm{pHs}$ (pH 5.2, 6.2 or 7.2), while the $\mathrm{pH}$ of the basolateral side was maintained at $\mathrm{pH}$ 7.2. The filters were then cut and the intracellular $\left[{ }^{14} \mathrm{C}\right] \mathrm{Gly}$-Sar was measured. Results are expressed as specific uptake of $\left[{ }^{14} \mathrm{C}\right] \mathrm{Gly}$-Sar calculated as described in the 'Materials and methods' section. Values represent means \pm s.e. of three determinations. ${ }^{* *} P<0.001$ and ${ }^{*} P<0.05$ for statistical significance between $\mathrm{pH} 5.2$ and $\mathrm{pH} 6.2$ or 7.2 ; ${ }^{\# \#} \mathrm{P}<0.001$ for statistical significance between $\mathrm{pH} 6.2$ and $\mathrm{pH}$ 7.2; NS, nonsignificant. of the KG-1 cell line. We performed uptake experiments of $20 \mu \mathrm{M}$ radiolabeled $\left[{ }^{14} \mathrm{C}\right] \mathrm{Gly}$-Sarcosine, in the presence or not of $20 \mathrm{mM}$ unlabeled Gly-Leu, at different $\mathrm{pHs}$, by Caco2-BBE cells either grown on filters or on 12-well plates, after different culture times. We first determined $15 \mathrm{~min}$ as the duration time of uptake from the linear range for experiments using Caco2-BBE cells grown on 12-well plates (Figure 4a). Uptake experiments performed at different pHs on confluent Caco2-BBE cells grown on 12-well plates after different times of culture showed that when cells are in the early stage of
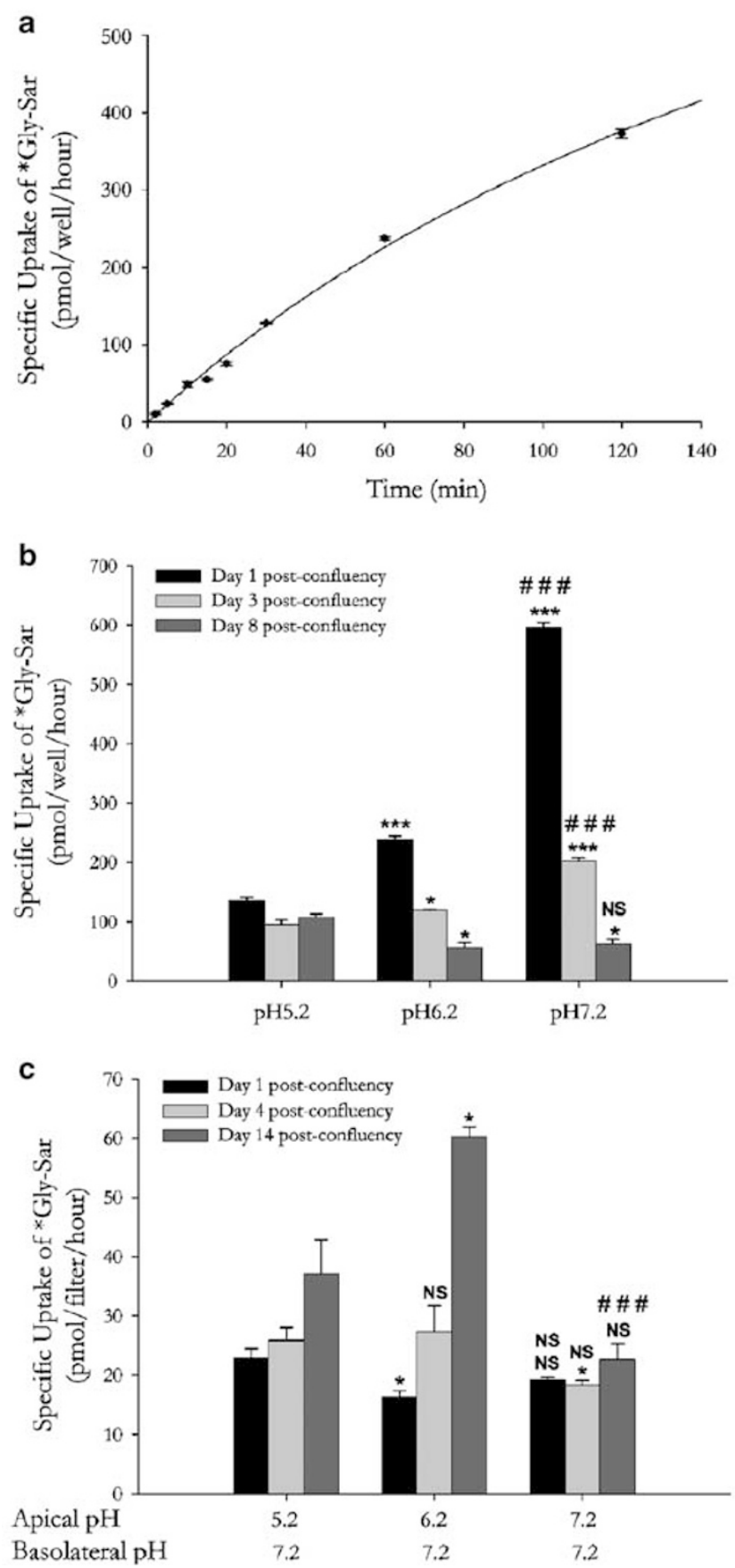
confluency (day 1 postconfluency), PepT-1 activity increased as the extracellular $\mathrm{pH}$ increased (Figure 4b; $135.66 \pm 5.38 \mathrm{pmol}\left[{ }^{14} \mathrm{C}\right]$ Gly-Sarcosine/well/h for $\mathrm{pH} 5.2$ vs $239.48 \pm 5.04$ for $\mathrm{pH} 6.2$ vs $595.96 \pm 8.27$ for $\mathrm{pH}$ 7.2) as it was observed for KG-1 cells. However at 3 days postconfluency, the difference of hPepT1 activity depending on the extracellular $\mathrm{pH}$ tended to be attenuated (Figure 4b; 96.45 \pm $5.93 \mathrm{pmol} \quad\left[{ }^{14} \mathrm{C}\right]$ Gly-Sarcosine/well/h for $\mathrm{pH} 5.2$ vs $119.33 \pm 0.94$ for $\mathrm{pH} 6.2$ vs $202.41 \pm 4.62$ for $\mathrm{pH}$ 7.2). While at 8 days postconfluency, the pattern of $\mathrm{pH}$-dependence tended to be reversed (Figure 4b; $107.6 \pm 5.22 \mathrm{pmol}\left[{ }^{14} \mathrm{C}\right] \mathrm{Gly}-S a r c o s i n e / w e l l / h$ for $\mathrm{pH}$ 5.2 vs $56.84 \pm 8.03$ for $\mathrm{pH} 6.2$ vs $63 \pm 7.98$ for $\mathrm{pH} 7.2$ ). This suggests that the pH-dependence of hPepT1mediated activity is associated with cell differentiation/polarization. To further examine this hypothesis, we performed uptake experiments, at different apical pHs, on confluent Caco2-BBE cells after different culture times on filter which allows them to fully differentiate and polarize. Figure 4c shows that when cells are taken at early stages of confluency (days 1 and 4 postconfluency), there are no significant differences of uptake whatever the apical $\mathrm{pH}$ is (day 1: $22.86 \pm 1.62$ pmol $\left[{ }^{14} \mathrm{C}\right]$ GlySarcosine /filter/h for $\mathrm{pH} 5.2$ vs $16.39 \pm 1.08$ for $\mathrm{pH}$ 6.2 vs $19.2 \pm 0.36$ for $\mathrm{pH} 7.2$; day $4: 25.89 \pm 2.18 \mathrm{pmol}$ $\left[{ }^{14} \mathrm{C}\right]$ Gly-Sarcosine/filter/h for $\mathrm{pH} 5.2$ vs $27.3 \pm 4.4$ for $\mathrm{pH} 6.2$ vs $18.32 \pm 6.2$ for $\mathrm{pH} 7.2$ ). These results show that apical $\mathrm{pH}$ does not play a major role in hPepT1-mediated uptake during early stages of confluency. However, at 14 days postconfluency, when cells are fully differentiated and polarized, we found that hPepT1 activity is optimal at $\mathrm{pH} 6.2$ (Figure 4c; $37.21 \pm 5.66 \mathrm{pmol} \quad\left[{ }^{14} \mathrm{C}\right]$ Gly-Sarcosine/ filter/h for $\mathrm{pH} 5.2$ vs $60.3 \pm 1.67$ for $\mathrm{pH} 6.2$ vs $22.63 \pm 2.76$ for $\mathrm{pH} 7.2$ ), which correlates what has already been described for differentiated and polarized Caco2-BBE cells grown on filters. ${ }^{22}$ This further confirms that the $\mathrm{pH}$-dependence of hPepT1 activity is associated with the differentiation and polarization state of cells. These results therefore explain the pattern of pH-dependence of hpepT1 activity observed in the KG-1 cell line.

\section{Cell Differentiation/Polarity Influences Membrane Permeability to Acids}

We hypothesized that the optimal uptake observed at basic pHs for nonpolarized cells is due to a disruption of the $\mathrm{pH}$ gradient between extracellular and intracellular compartments,that is, a disruption of the driving force of hPepT1-mediated transport caused by increased permeability of nonpolarized cells to $\mathrm{H}^{+}$when they are incubated in acidic media. To further investigate this hypothesis, we performed intracellular $\mathrm{pH}$ measurements of polarized and nonpolarized cells before and after acidification of the extracellular medium. Nonpolarized (Figure 5a) and polarized (Figure 5b) cells were incubated in HBSS/10 mM MES at $\mathrm{pH} 7.2$ and measurements of intracellular $\mathrm{pH}$ were taken as described in the 'Materials and methods' section. After $3 \mathrm{~min}$, HCl $0.1 \mathrm{~N}$ was added in the extracellular medium of nonpolarized cells and in the apical compartment of polarized cells in order to set the incubation buffer at $\mathrm{pH}$ 6.2. Figure 5a shows that when nonpolarized Caco2-BBE cells were incubated in a buffer at $\mathrm{pH} 7.2$, they maintained an intracellular $\mathrm{pH}$ of about $7.4(\mathrm{pH} 7.45 \pm 0.04)$. However after acidification of the incubation buffer, nonpolarized cells underwent a drastic decrease of their intracellular $\mathrm{pH}$ (Figure 5a; $\mathrm{pH} 6.11 \pm 0.02$ at the end of the experiment). Figure $5 \mathrm{~b}$ shows that polarized cells, incubated in a pH 7.2-buffered medium, maintained an intracellular $\mathrm{pH}$ of about $7.4(\mathrm{pH} 7.45 \pm 0.07)$, which did not undergo drastic changes upon acidification of the apical compartment $(\mathrm{pH}$ $6.83 \pm 0.11$ at the end of the experiment). These results show that nonpolarized and polarized cells have a differential permeability to $\mathrm{H}+$. Consistent with this finding and with the results found for the uptake experiments, KG-1 cells underwent an immediate drop of their intracellular $\mathrm{pH}$ after acidification of the extracellular medium (Figure 5c; from $\mathrm{pH} 6.95$ at the beginning of the experiment to $\mathrm{pH} 6.15$ at the end of the experiment).

\section{The Monocytic KG-1 Cell Line Expresses a Functional hPepT1 Transporter after Differentiation into Macrophage-Like Cells}

KG-1 cells have been described to differentiate into macrophage-like cells upon treatment with PMA. ${ }^{23,24}$ We therefore treated KG-1 cells with $100 \mathrm{nM}$ PMA for 4 days. Figure 6a represents a picture of undifferentiated KG-1 cells and Figure $6 \mathrm{~b}$ represents a picture of KG-1 cells differentiated into macrophage-like cells after treatment with PMA. Differentiated KG-1 cells were then used as a model of human macrophages to assess for the uptake of $\left[{ }^{3} \mathrm{H}\right]$ fMLP in the presence or not of Gly-Leu. First we examined the expression of hPepT1 in KG-1 cells differentiated into macrophages by immunofluorescence staining. Figure 6c shows that KG-1 cells still express hPepT1 when they are differentiated into macrophages. Uptake experiments of $\left[{ }^{3} \mathrm{H}\right] \mathrm{fMLP}$ by differentiated KG-1 cells showed that fMLP was transported into macrophage-like cells (Figure 6d; $480.03 \pm 23.65 \mathrm{fmol}\left[{ }^{3} \mathrm{H}\right] \mathrm{fMLP} /$ well/h) and this transport was inhibited by Gly-Leu (Figure 6d; $61.63 \pm 2.55 \mathrm{fmol}\left[{ }^{3} \mathrm{H}\right] \mathrm{fMLP} /$ well/h). This demonstrates that human macrophage-like cells retained hPepT1-mediated fMLP transport across their membranes. Figure 6e shows that PMAinduced differentiation of KG-1 cells into macrophages-like cells does not affect the $\mathrm{pH}$ dependence pattern of $\left[{ }^{14} \mathrm{C}\right] \mathrm{Gly}$-Sarcosine transport; the uptake increased as the extracellular $\mathrm{pH}$ increased. 


\section{Discussion}

The functional characteristics of hPepT1 have been established in polarized epithelial cells such as Caco2-BBE monolayers. ${ }^{4,9,16,21}$ Polarized epithelial cells contain apical and basolateral membrane domains with unique protein and lipid composition. The asymmetric distribution of plasma membrane components is a fundamental characteristic of epithelial cells, and the asymmetric distribution of ion transport processes within these membranes is closely linked to the ability of the epithelium to secrete or absorb fluid. In simple epithelia and in clonal, polarized epithelial cell lines, this composition is repeated in neighboring cells, resulting in a contiguous, single cell layer with barrier and transport functions. In contrast, nonpolarized cells
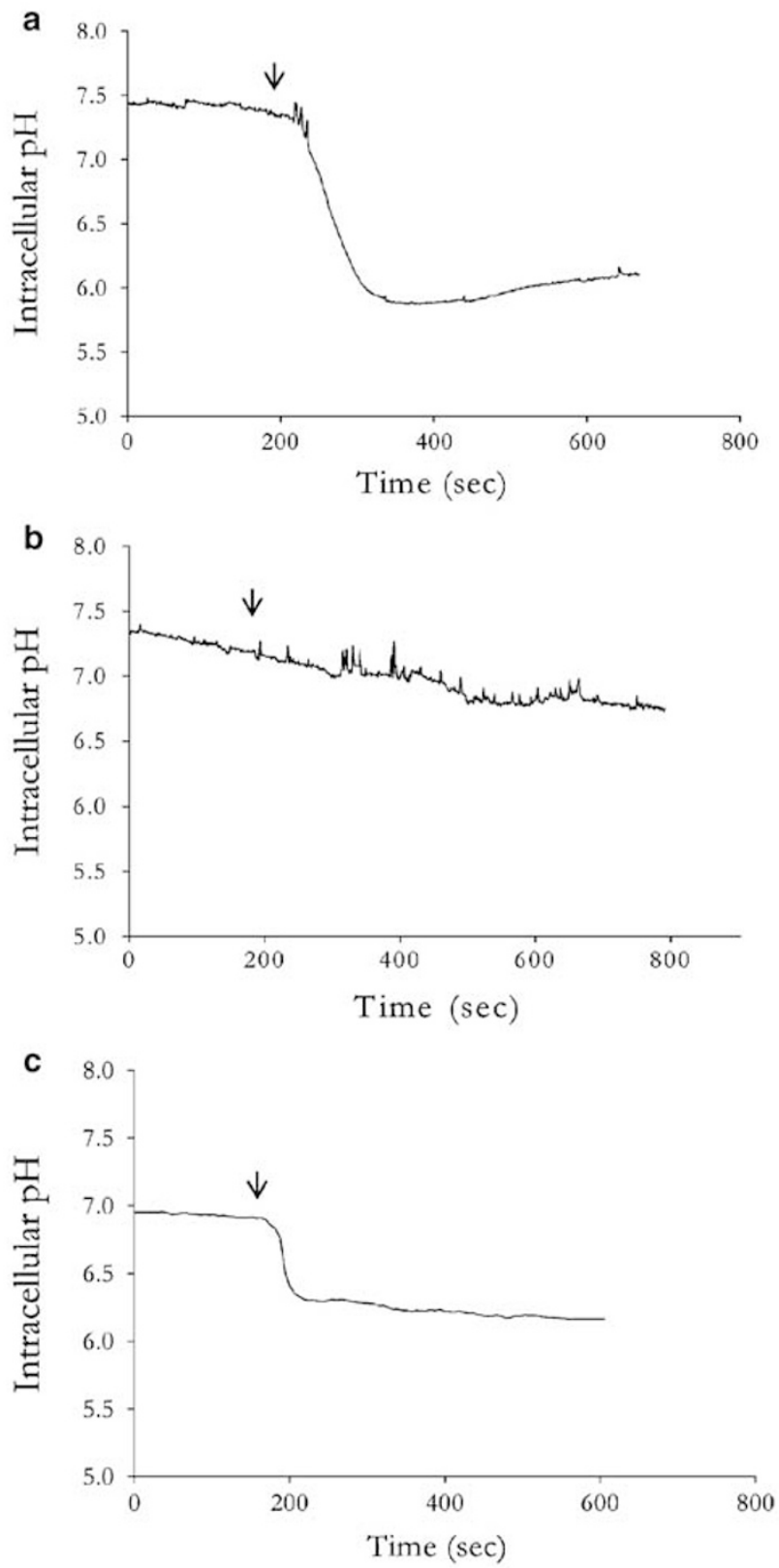

have only one membrane domain. This may change the interrelationships among transport molecules such as hPepT1. Thus, it is interesting that hPepT1 is not only expressed in polarized epithelial cells but we herein show that it is also expressed in nonpolarized immune cells.

Immune cells such as macrophages are in close contact with the lamina propria of the small intestine, ${ }^{25,26}$ where small bacterial peptide products are present. Interestingly, it has been shown that macrophages expressing triggering receptor expressed on myeloid cells-1 (TREM-1), which is a receptor on neutrophils and monocytes/macrophages involved in inflammatory responses, are under-represented in the human intestine. ${ }^{27}$ This suggests that some other receptor(s) are involved in the development of immune response by these cells. Under normal conditions, a constant low concentration of fMLP is in contact with macrophages, leading to a physiological baseline level of inflammation. ${ }^{15}$ Consistent with this, the $\mathrm{ED}_{50}$ of the fMLP receptor is in the nM range, ${ }^{12}$ allowing passive movement of fMLP across the tight junctions of the epithelium under normal conditions.

However, during inflammation, colonic tissues express hPepT1, ${ }^{,, 16}$ leading to two main consequences. First, the intracellular accumulation of fMLP induces an epithelial inflammatory response, including activation of the $\mathrm{NF}-\kappa \mathrm{B}$ pathway and immune accessory molecules such as MHC class I. ${ }^{9}$ Second, hPepT1 expression participates in the active transcellular transport of fMLP from the lumen to the lamina propria. Previous studies have shown that under inflammatory conditions, fMLP translocation across the epithelium via both paracellular and transcellular pathways are increased. However, no previous work has examined the expression of hPepT1 by human immune cells.

Figure 5 Cell differentiation/polarity influences membrane permeability to acids. Nonpolarized Caco2-BBE cells (a), polarized Caco2-BBE cells (b) and KG-1 cells (c) were loaded with the fluorescent dye BCECF-AM and assessed for intracellular $\mathrm{pH}$ measurements as described in 'Materials and methods'. For each cell line and cell culture condition, two independent experiments with at least three assays per experiment were performed. For experiments using Caco2-BBE cells, 30 cells per monolayer were selected for single cell intracellular $\mathrm{pH}$ assay. (a) Represents the mean of intracellular $\mathrm{pH}$ in the selected cells from one assay, that is, from one monolayer of Caco2-BBE grown on plastic $(\mathrm{pH}$ $7.45 \pm 0.04$ at the beginning of the experiment and $\mathrm{pH} 6.11 \pm 0.02$ at the end of the experiment). (b) Represents the mean of intracellular $\mathrm{pH}$ in the selected cells from one assay, that is, from one monolayer of Caco2-BBE grown on filter $(\mathrm{pH} 7.4 \pm 0.07$ at the beginning of the experiment and $\mathrm{pH} 6.83 \pm 0.11$ at the end of the experiment). For each assay using KG-1 cells, a suspension of 200000 cells was assessed for intracellular $\mathrm{pH}$ measurement. (c) Represents the intracellular $\mathrm{pH}$ measured in one assay, that is, in a cell suspension containing 200000 cells $(\mathrm{pH} 6.95$ at the beginning of the experiment and $\mathrm{pH} 6.15$ at the end of the experiment). The data shown in (a)-(c) are representative of the results found in the other assays. Cells were initially incubated in HBSS $/ 10 \mathrm{mM}$ at $\mathrm{pH}$ 7.2. The red arrows indicate the time when the extracellular/apical $\mathrm{pH}$ was changed from 7.2 to 6.2 by addition of $\mathrm{HCl} 1 \mathrm{~N}$. 


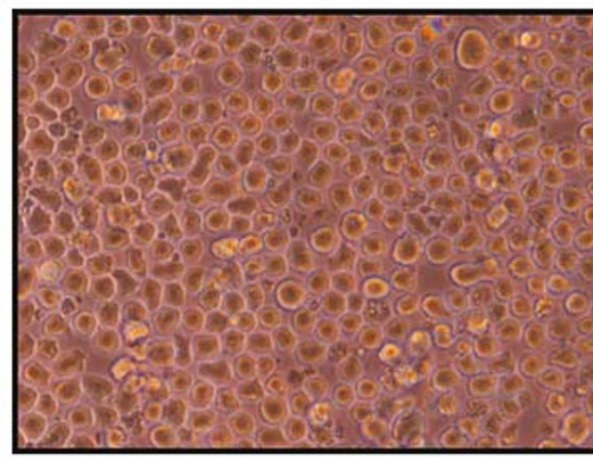

b

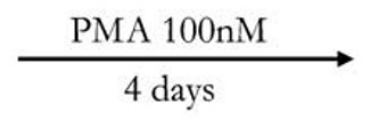

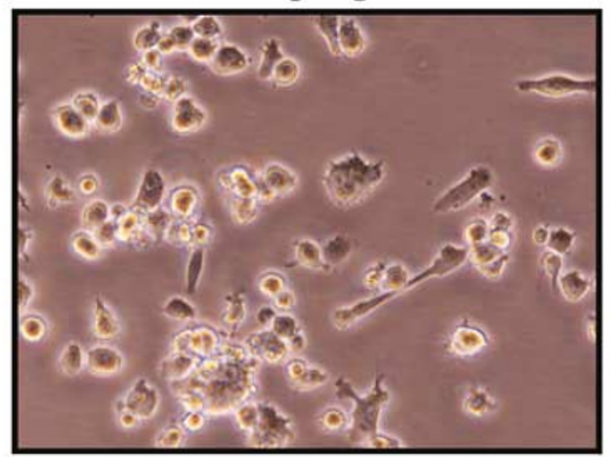

C

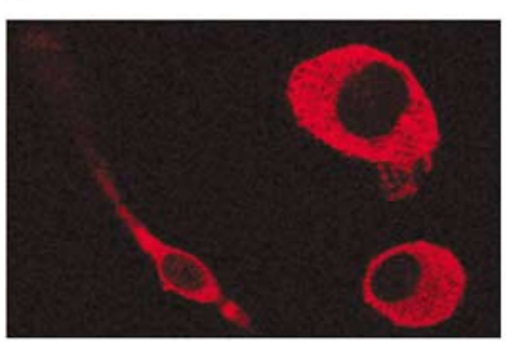

d

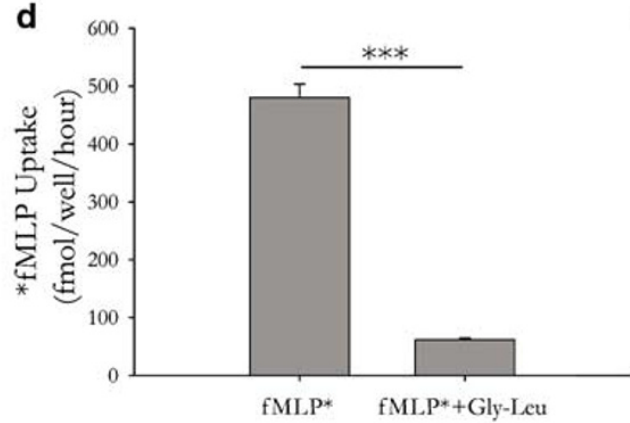

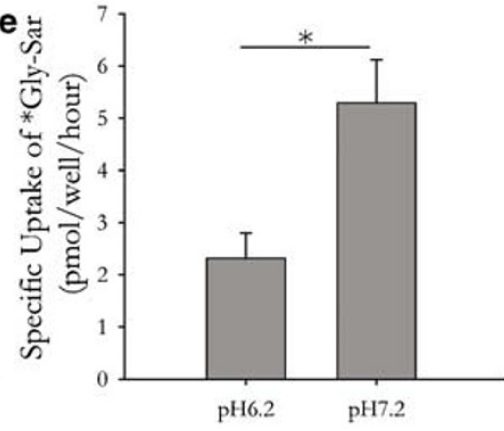

Figure 6 hPepT1 transports fMLP in KG-1 cells differentiated into macrophages. Treatment of KG-1 cells (a) with $100 \mathrm{nM}$ PMA for 4 days induces differentiation into macrophage-like cells (b). Original magnification $\times 400$. (c) Immunofluorescence staining of hPepT1 on KG-1 cells after differentiation into macrophage-like cells, using polyclonal rabbit anti-hPepT1 antibody. Pictures were taken using a confocal microscope. Original magnification $\times 63$. (d) KG-1 cells, differentiated into macrophage-like cells, were incubated with $0.15 \mu \mathrm{M}$ $\left[{ }^{3} \mathrm{H}\right] \mathrm{fMLP} \pm 20 \mathrm{mM}$ Gly-Leu at $\mathrm{pH} 7.2$, and the amount of fMLP accumulated by the cells was determined by liquid scintillation counting. (e) hPepT1-mediated uptake of $\left[{ }^{14} \mathrm{C}\right] \mathrm{Gly}$-Sar uptake is increased by basic pHs in KG-1 cells differentiated into macrophage-like cells. Uptake experiments of $20 \mu \mathrm{M}\left[{ }^{14} \mathrm{C}\right] \mathrm{Gly}-\mathrm{Sar} \pm 20 \mathrm{mM}$ Gly-Leu by differentiated KG-1 cells were performed at different extracellular pHs ( $\mathrm{pH} 6.2$ or 7.2). Cells were then lysed and the remaining intracellular $\left[{ }^{14} \mathrm{C}\right] \mathrm{Gly}$-Sar was measured. Results are expressed as specific uptake of $\left[{ }^{3} \mathrm{H}\right] \mathrm{fMLP}$ or $\left[{ }^{14} \mathrm{C}\right] \mathrm{Gly}$-Sar calculated as described in the 'Materials and methods' section. Values represent means \pm s.e. of three determinations. ${ }^{* *} P<0.001 ;{ }^{*} P<0.05$.

Here, we demonstrated that hPepT1 is expressed in KG-1 cells. These cells show considerable pleomorphism with most cells at the myeloblast and promyeloblast stages. ${ }^{23,24}$ Myeloblasts are the most morphologically immature cells in the myeloid series and they differentiate into both neutrophilic granulocytes and monocytes, the latter of which can further develop into tissue macrophages. As it is the case with most hematopoietic cells, KG-1 cells express HLA-A and HLA-B antigens. ${ }^{24}$ The expression of hPepT1 in undifferentiated immune cells suggests that hPepT1 might play an important role in the differentiation of these cells.

In this work, we used KG-1 cells to show for the first time that hPepT1 transports di- and tripeptides in human immune cells. RT-PCR experiments showed that hPepT2 is expressed in KG-1 cells, as well as in human normal mononuclear cells from peripheral blood (data not shown). However, based on the observed $K_{\mathrm{m}}(2.9 \mathrm{mM})$, the di- and tripeptide uptake by KG-1 cells is mainly due to hPepT1 $\left(K_{\mathrm{m}}\right.$ in $\mathrm{mM}$ range) and not to hPepT2 $\left(K_{\mathrm{m}}\right.$ in $\mu \mathrm{M}$ range $)$.

Interestingly, hPepT1-mediated di- and tripeptide transport in these cells decreased under low extra- cellular $\mathrm{pH}$ conditions. This seems surprising, as imposition of a proton gradient was shown to stimulate dipeptide uptake by brush border membrane vesicles (BBMVs) of the human intestinal mucosa and by the apical plasma membrane of Caco2-BBE monolayers. ${ }^{21}$ Uptake experiments performed at different $\mathrm{pHs}$ on Caco2-BBE cells grown either on plastic or on filters, after different times of culture, strongly suggest that the $\mathrm{pH}$-dependence of hPepT1 is associated with the differentiation state and more especially by cell polarity. We hypothesized that the decreased uptake observed at acidic pHs for nonpolarized cells is due to increased permeability of cells to $\mathrm{H}^{+}$when they are not polarized, leading to a disruption of the $\mathrm{pH}$ gradient between extracellular and intracellular compartments and therefore to a disruption of the driving force of hPepT1-mediated transport. This hypothesis is supported by (1) our findings that nonpolarized Caco2-BBE cells and KG-1 cells underwent drastic decreases of intracellular $\mathrm{pH}$ following acidification of the incubation buffer, while intracellular $\mathrm{pH}$ of polarized Caco2-BBE cells remained constant and (2) a previous report from our group 


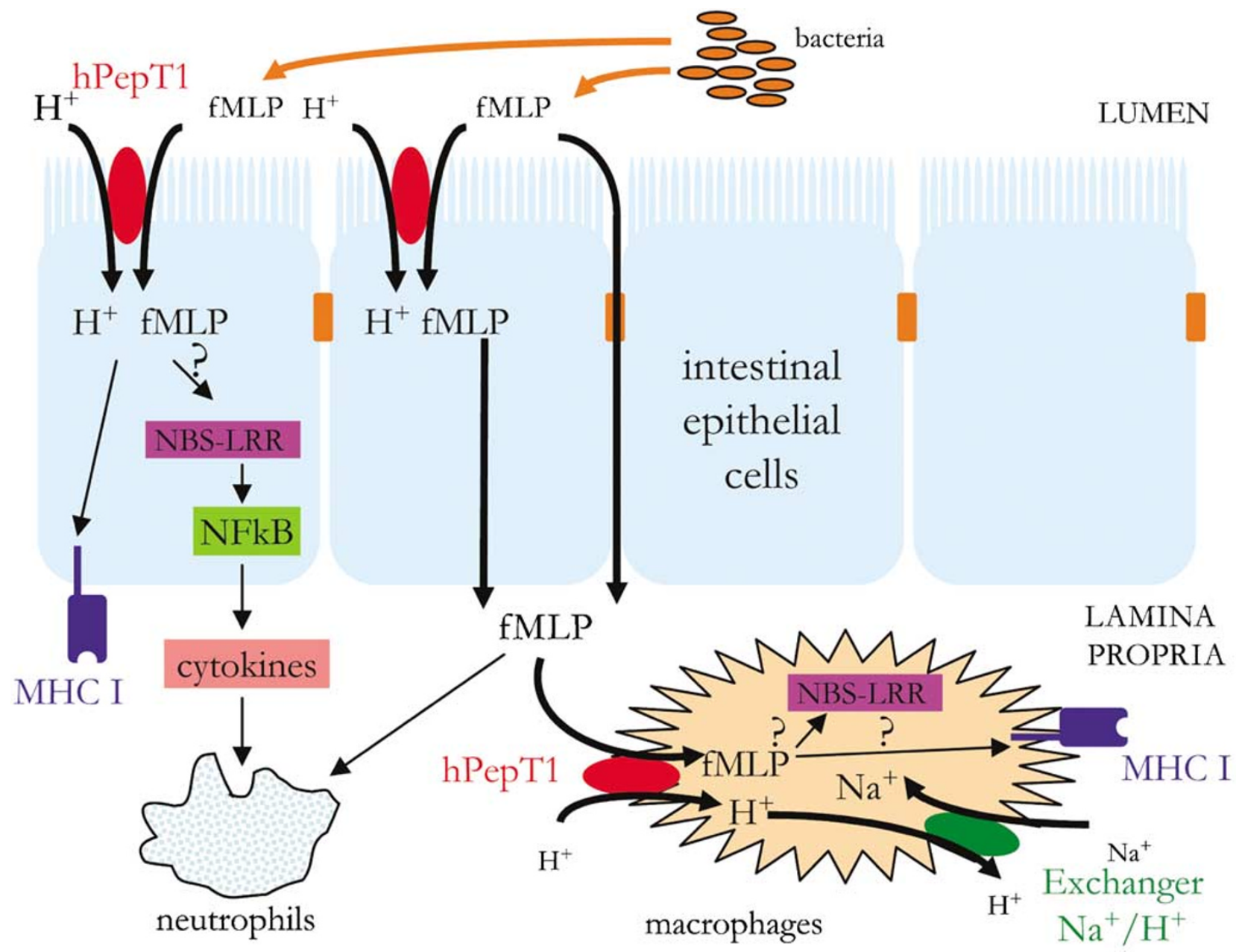

Figure 7 Proposed model for the role of hPepT1 in intestinal inflammation. The bacterial product fMLP is normally present in the intestinal lumen. Intestinal hPepT1, which is expressed in inflamed but not in non-inflamed intestinal colonic epithelial cells, mediates fMLP transport into the cytosol. The arrival of these small bacteria peptides into the cytosol induces MHC activation and cytokine secretion via the activation of NF-kB. Moreover an efflux of fMLP across the basolateral membrane has already been described and the existence of a basolateral peptide transporter has been shown. ${ }^{4,34}$ Therefore fMLP and other small formylated peptides may be taken up by macrophages present in the lamina propria. The presence of these small formylated peptides may participate in the activation of an immune response by intracellular receptors, such as the NBS-LRR proteins (eg NOD2) that are involved in intracellular recognition of microbes and their products. ${ }^{15}$

showing that an increase of intracellular $\mathrm{pH}$ induced by interferon-gamma (IFN $\gamma$ ) in polarized Caco2-BBE cells enhanced hPepT1-mediated uptake. ${ }^{16}$

The fact that intracellular $\mathrm{pH}$ of polarized Caco2BBE cells did not undergo any major changes after acidification of the apical $\mathrm{pH}$ is consistent with the ability of the intestinal epithelium to maintain an apical-to-intracellular $\mathrm{pH}$ gradient. Impermeability to acid of apical cell membrane has already been described for alveolar epithelial cells. ${ }^{28}$ This difference of permeability to $\mathrm{H}^{+}$in polarized and nonpolarized cells could be due to the fact that membrane proteins are segregated into two different membrane domains in polarized cells, therefore the communications/interactions between transporters/ exchangers/channels and others is different from those in nonpolarized cells. In addition, polarized cells have tight junctions that are known to be impermeable to $\mathrm{H}^{+28}$ and which also account for the high transepithelial electrical resistance (TER) observed for well-differentiated/polarized cells..$^{29,30}$

In $\mathrm{Na}^{+}$-free media, acidification of the extracellular medium increased hPepT1 activity in KG-1 cells, as expected for a symporter, with an optimum $\mathrm{pH}$ of 5.2. The opposite effect in $\mathrm{Na}^{+}$-containing media can be interpreted as an activation of the $\mathrm{Na}^{+} / \mathrm{H}^{+}$exchange responsible for maintenance of the proton motive force. ${ }^{31}$ We confirmed a direct coupling between $\mathrm{Na}^{+} / \mathrm{H}^{+}$and hPepT1 by showing that $\mathrm{Na}^{+}$-dependence was not observed in hPepT1mediated di- and tripeptide transport at $\mathrm{pH}$ 5.2. We showed by RT-PCR (Figure 3e) that NHE1, NHE2 and, to a lesser extent, NHE3 are expressed in KG-1 cells. This suggests that at least one of these isoforms can be involved in the coupling to hPepT1-mediated uptake. In addition, we demonstrated that hPepT1 activity was reduced in the presence of DIDS or in the absence of $\mathrm{Cl}^{-}$. As it has been shown 
that $\mathrm{NHE} 3$ and $\mathrm{Cl}^{-} / \mathrm{OH}^{-}$exchange processes are functionally coupled, ${ }^{32}$ it is reasonable to think that one NHE isoform and $\mathrm{Cl}^{-} / \mathrm{OH}^{-}$exchange processes could be functionally coupled and contribute to hPepT1-mediated uptake in KG-1 cells.

Collectively, these results show that hPepT1 is expressed in the nonpolarized KG-1 cell line and that in these cells, the optimal activity of hPepT1 is seen at $\mathrm{pH} 7.2$, which is the $\mathrm{pH}$ in the immune cell environment. In contrast, hPepT1 is expressed in polarized intestinal epithelial monolayers, the oligopeptide transporter functions optimally at a lower $\mathrm{pH}$.

Finally, we demonstrated that hPepT1 is not only expressed in immature immune cells but also in differentiated human macrophages. The expression of hPepT1 in antigen-presenting cells might have important physiological relevance. For example, bacterial peptides such as fMLP, which are transported by hPepT1, ${ }^{4,5,9}$ could be taken up by macrophages to participate in the intestinal inflammatory immune response. We propose that during intestinal inflammation, luminal-derived antigens such as fMLP may be taken up by macrophages present in diffuse aggregates in the lamina propria (Figure 7). The presence of these small formylated peptides may participate in the activation of an immune response by antigen presentation via MHC class I or II molecules, ${ }^{33}$ or may be recognized by intracellular receptors such as the NBS-LRR proteins (eg NOD2), which are involved in intracellular recognition of microbes and their products (Chamaillard et $a ;^{15}$ Figure 7).

\section{Acknowledgements}

This work was supported by National Institute of Diabetes and Digestive and Kidney Diseases under center grant (R24-DK-064399) and National Institute of Health grants DK061941 to D Merlin, DK064711 to S Sitaraman, and DK062899 to JM Klapproth. L Charrier is supported by the Crohn's and Colitis Foundation of America and Elvin and Janet Price. Y Yan is a recipient of a Research Award from the Crohn's and Colitis Foundation of America.

\section{Duality of interest}

None declared.

\section{References}

1 Marasco WA, Phan SH, Krutzsch H, et al. Purification and identification of formyl-methionyl-leucyl-phenylalanine as the major peptide neutrophil chemotactic factor produced by Escherichia coli. J Biol Chem 1984;259:5430-5439.
2 Chadwick VS, Mellor DM, Myers DB, et al. Production of peptides inducing chemotaxis and lysosomal enzyme release in human neutrophils by intestinal bacteria in vitro and in vivo. Scand J Gastroenterol 1988;23:121-128.

3 Daniel H. Molecular and integrative physiology of intestinal peptide transport. Annu Rev Physiol 2004; 66:361-384.

4 Merlin D, Steel A, Gewirtz AT, et al. hPepT1-mediated epithelial transport of bacteria-derived chemotactic peptides enhances neutrophil-epithelial interactions. J Clin Invest 1998;102:2011-2018.

5 Vavricka SR, Musch MW, Chang JE, et al. hPepT1 transports muramyl dipeptide, activating NF-kappaB and stimulating IL-8 secretion in human colonic Caco2/bbe cells. Gastroenterology 2004;127:1401-1409.

6 Groneberg DA, Doring F, Eynott PR, et al. Intestinal peptide transport: ex vivo uptake studies and localization of peptide carrier PEPT1. Am J Physiol Gastrointest Liver Physiol 2001;281:G697-G704.

7 Ogihara H, Saito H, Shin BC, et al. Immuno-localization of $\mathrm{H}+$ /peptide cotransporter in rat digestive tract. Biochem Biophys Res Commun 1996;220:848-852.

8 Sai Y, Tamai I, Sumikawa H, et al. Immunolocalization and pharmacological relevance of oligopeptide transporter PepT1 in intestinal absorption of beta-lactam antibiotics. FEBS Lett 1996;392:25-29.

9 Merlin D, Si-Tahar M, Sitaraman SV, et al. Colonic epithelial hPepT1 expression occurs in inflammatory bowel disease: transport of bacterial peptides influences expression of MHC class 1 molecules. Gastroenterology 2001;120:1666-1679.

10 Ziegler TR, Fernandez-Estivariz C, Gu LH, et al. Distribution of the $\mathrm{H}+$ /peptide transporter PepT1 in human intestine: up-regulated expression in the colonic mucosa of patients with short-bowel syndrome. Am J Clin Nutr 2002;75:922-930.

11 Buyse M, Tsocas A, Walker F, et al. PepT1-mediated fMLP transport induces intestinal inflammation in vivo. Am J Physiol Cell Physiol 2002;283:C1795C1800.

12 Le Y, Murphy PM, Wang JM. Formyl-peptide receptors revisited. Trends Immunol 2002;23:541-548.

13 Eckmann L. Innate immunity and mucosal bacterial interactions in the intestine. Curr Opin Gastroenterol 2004;20:82-88.

$14 \mathrm{Ku}$ CL, Yang K, Bustamante J, et al. Inherited disorders of human Toll-like receptor signaling: immunological implications. Immunol Rev 2005;203:10-20.

15 Chamaillard M, Girardin SE, Viala J, et al. Nods, Nalps and Naip: intracellular regulators of bacterial-induced inflammation. Cell Microbiol 2003;5:581-592.

16 Buyse M, Charrier L, Sitaraman S, et al. Interferongamma increases hPepT1-mediated uptake of ditripeptides including the bacterial tripeptide fMLP in polarized intestinal epithelia. Am J Pathol 2003;163: 1969-1977.

17 Buyse M, Sitaraman SV, Liu X, et al. Luminal leptin enhances CD147/MCT-1-mediated uptake of butyrate in the human intestinal cell line Caco2-BBE. J Biol Chem 2002;277:28182-28190.

18 Buyse M, Berlioz F, Guilmeau S, et al. PepT1-mediated epithelial transport of dipeptides and cephalexin is enhanced by luminal leptin in the small intestine. J Clin Invest 2001;108:1483-1494.

19 Charrier L, Yan Y, Driss A, et al. ADAM-15 inhibits wound healing in human intestinal epithelial cell 
monolayers. Am J Physiol Gastrointest Liver Physiol 2005;288:G346-G353.

20 Thomas JA, Buchsbaum RN, Zimniak A, et al. Intracellular $\mathrm{pH}$ measurements in Ehrlich ascites tumor cells utilizing spectroscopic probes generated in situ. Biochemistry 1979;18:2210-2218.

21 Adibi SA. Regulation of expression of the intestinal oligopeptide transporter (Pept-1) in health and disease. Am J Physiol Gastrointest Liver Physiol 2003;285: G779-G788.

22 Saito H, Motohashi H, Mukai M, et al. Cloning and characterization of a $\mathrm{pH}$-sensing regulatory factor that modulates transport activity of the human $\mathrm{H}+/$ peptide cotransporter, PEPT1. Biochem Biophys Res Commun 1997;237:577-582.

23 Koeffler HP, Golde DW. Acute myelogenous leukemia: a human cell line responsive to colony-stimulating activity. Science 1978;200:1153-1154.

24 Koeffler HP, Golde DW. Human myeloid leukemia cell lines: a review. Blood 1980;56:344-350.

25 Smith PD, Smythies LE, Mosteller-Barnum M, et al. Intestinal macrophages lack CD14 and CD89 and consequently are down-regulated for LPS- and IgAmediated activities. J Immunol 2001;167:2651-2656.

26 Smythies LE, Sellers M, Clements RH, et al. Human intestinal macrophages display profound inflammatory anergy despite avid phagocytic and bacteriocidal activity. J Clin Invest 2005;115:66-75.
27 Schenk M, Bouchon A, Birrer S, et al. Macrophages expressing triggering receptor expressed on myeloid cells-1 are underrepresented in the human intestine. J Immunol 2005;174:517-524.

28 Joseph D, Tirmizi O, Zhang XL, et al. Polarity of alveolar epithelial cell acid-base permeability. Am J Physiol Lung Cell Mol Physiol 2002;282:L675-L683.

29 Claude P, Goodenough DA. Fracture faces of zonulae occludentes from 'tight' and 'leaky' epithelia. J Cell Biol 1973;58:390-400.

30 Claude P. Morphological factors influencing transepithelial permeability: a model for the resistance of the zonula occludens. J Membr Biol 1978;39:219-232.

31 Thwaites DT, Kennedy DJ, Raldua D, et al. H/dipeptide absorption across the human intestinal epithelium is controlled indirectly via a functional $\mathrm{Na} / \mathrm{H}$ exchanger. Gastroenterology 2002;122:1322-1333.

32 Saksena S, Gill RK, Tyagi S, et al. Involvement of c-Src and protein kinase $\mathrm{C}$ delta in the inhibition of $\mathrm{Cl}(-) /$ $\mathrm{OH}$-exchange activity in Caco-2 cells by serotonin. J Biol Chem 2005;280:11859-11868.

33 Vyas JM, Rodgers JR, Rich RR. H-2M3a violates the paradigm for major histocompatibility complex class I peptide binding. J Exp Med 1995;181:18171825.

34 Irie M, Terada T, Okuda M, et al. Efflux properties of basolateral peptide transporter in human intestinal cell line Caco-2. Pflugers Arch 2004;449:186-194. 